\title{
Poetic Utterances and Socio-Political Commitment in Obasa's Poems
}

\author{
Lere Adeyemi \\ Department of Linguistics and Nigerian Languages \\ University of llorin \\ Nigeria \\ adeyemiolalere@yahoo.com
}

\begin{abstract}
Yorùbá literary critics such as Ollabimtan (1974a), Fọlọrunṣọ (1998), among others, have classified D. A. Obbasá as a unique colonial poet whose poems were committed to the promotion of Yorùbá cultural heritage. Thus, a lot of critical works that exist on Opbasa's poems largely concentrate on the cultural and the philosophical dimensions with little or no focus on the socio-political commitment of the poet. The objective of this study therefore, was to examine the socio-political commitment of Obasa and his poetic utterances. The research methodology is descriptive. It is a corpus study or content analysis of the poetry books. Poems that are relevant to socio-political issues in the three books (İwé Kinni Awọn Akéwì İwé Kejì Awọn Akéwì and İwé Kẹ́ta Àwọn Akéwi) were analyzed within the theory of Nativism. The major findings of the study were that: the selected poems have diverse socio-political themes as related to traditional politics, colonial politics, Yorùbá civil wars, first world war, migration and the need to remember one's home or country; some of the poems were used as viable tool for political education; while others were essentially to ignite political consciousness in the readers. The paper concluded that Ọbasá was a committed poet who used his poetic utterances to disseminate, analyze, and educate the readers on the socio-political climate of colonial days. His non-violence ideological position in resolving socio-political issues is in consonance with the theory of Nativism and it is recommended for modern Yorùbá society and other African societies.
\end{abstract}




\section{Introduction}

There have been arguments and counter arguments between formalist critics and literary sociologists on the relationship between poetry and political commitment. The formalist critics are generally upset by politically committed poetry. The argument, according to Kirpal (1989) is that "frequently political poetry is no better than political propaganda" (181). It is also feared that sloganizing, general polemicising, will take over from the more subtle art of suggestion. Formalist theorists find fault with the tendency to link the works of literature with extra-literary references as the author, the context of writing and the dominant ideology. Rylance (1987), asserts that "honest criticism and sensitive appreciation is directed not upon the poet but upon poetry" (8). In other words, critics are called to focus on the structure of the language and not the message of the poet to the society. However, literary sociologists have made it clear that there is no "neutral literature." And that every work of art is societal-based and it reflects and refracts the happenings in the society of the author. In the area of political commitment, literary sociologists assert that no writing can be truly neutral. D'Almeida (1974) for example, confirms this view when he says that, "Any kind of writing is committed, one way or the other. There can be no neutrality in literature and one should say not being committed is still being committed to non-commitment" (1). Orwell (1982), cited in Ogunsina (2006), strengthens this viewpoint when he declares: "No book is genuinely free from political bias. The opinion that art should have nothing to do with politics is in itself a political attitude" (13). Kumar (2014) asserts that in recent times, critics and theorists have problematized the concept of a literary artifact as expressing an unchanging human nature. According to him, "no utterance is now considered innocuous" (178). Our position in this study is that poetry and politics are inseparable. Poets are members of the society and their poems are reflections of the socio-political and cultural happenings of the society.

Current theories have displaced the liberal humanist concept of "Universal" literature. Even the works that have no overt political overtones are held to be political "since even the choice to eschew explicit political involvement or references constitutes a form of political action" (Dasenbrock, 2001: 51).

Yorùbá poets have been making political utterances in their poetry right from the pre-colonial period till date. In traditional Yorùbá society, a poet was considered as a kind of guru, a sage to whom people look up to for guidance. Traditional poets involved themselves intimately with political issues. In the colonial era, Yorùbá poets who used the medium of writing were also committed to political issues. They made poetic utterances which most of the time were politically correct. Notable Yorùbá poets in the colonial period were 
Arobiodu, Oguji, Odunjọ, Kilanko, Ajisafẹ and Ọbasá whose poems were categorized by Olabimtan (1987) as "protest poetry" or "poetry engage" (3). In an earlier work Olabimtan (1974a) identifies Obasa as unique among the colonial poets of his time. He states that unlike orin-àrùngbè poets led by Sobo Arobiodu, who used the Egba dialect, Ọbasa did not use his hometown's dialect (the Ifẹ dialect) in his poems; he used the standard Yoruba language to make his poems readable by all the Yorùbá readers. Secondly, unlike Oddunjọ, Kilanko and other àrùngbè poets, Obasa did not confine himself to a particular form of Yoruba society; he did not fancy borrowed forms of poetic composition like others, and, on his own, spent many years to collect and study Yorùbá oral poems from various artists to develop his expertise before embarking on poetry writing. One other thing that is visible in the poems of Obasa is his commitment to socio-political issues as related to the colonial period. One can observe the passion with which Obasa shares his views on the political climate during the colonial era. This is in consonance with the words of Kirpal (1989) that, "poetic utterances will remain sterile unless the passion is shared and that the passion of politically committed poetry allows for cross-fertilization of ideas between the 'thinkers' and 'hearers' who undergo the same political experience" (182). Any analysis of Obasa's poetry has to be situated within the colonial political context because his poems actively respond to the socio-political issues of his time. Obasa's poetic utterances in the three poetry books are so fascinating and pungent on political matters during the colonial era. Babalola (1991) comments on the acceptance of the reading public that: "All three were well received at the time of their publication, and from then on have been held in high esteem, especially for making Yorùbá gnomic lore available in written classified form" (191).

How does Obasa explain the sociopolitical themes or issues of his society in Iwe Kiiní ti Awọn Akéwì, İwé Kejì ti Awọn Akéwì and İwé Kẹtạ ti Awọn Akéwi? What type of commitment can we identify in his political poems? Conservative or progressive, liberal or radical, revolutionary or reactionary; conformist or non-conformist. Political poetry relies heavily on history and context. How does he use the colonial Nigeria political context to make his poetic utterances? What lessons can the present society learn from his ideological standpoint as a political poet? This paper would answer these and other questions through the literary lens of Obasa's political poems.

The research methodology is descriptive. We adopt sampling technique to select the relevant poems that bother on socio-political matters. The selected poems are: "İgbà Òibó," and "Adámalèsee" in İwe Kejì ti Awọn Akéwì and "İlú Ilọrin," "Aláșejù," "Pẹleẹpẹ̣lẹe," and "Elétò-ètò" in İwé Kìní ti Awọn Akéwì. The selected poems are subjected to critical reading and content analysis within the theory of Nativism, a critical perspective under the Postcolonial theory. 


\section{Critical Perspective}

Postcolonial theory emerges from an interdisciplinary area of study that is concerned with the historical, political, philosophical, socio-cultural and aesthetic structures of colonial domination and resistance. It refers to a way of reading, theorizing, interpreting and investigating colonial agenda. Postcolonial theory as a theoretical and critical activity, establishes itself as a subversive discourse against European cultural and academic imperialism. It negates colonial and neo-colonial constructions and assumptions in literature. There are many models of postcolonial theory but the relevant model for this study is Nativism and it has become a theory on its own.

Within the context of Yorùbá history, Nativism (Nativity) has been a twofold concept, one negative and the other positive. The negative concept is used to abuse the people implemented through socio-political, cultural and lingual subjugation and oppression, terms such as 'native authority', 'native people', 'native language', 'native medicine', and 'native dress' as forms of anthropological descriptions of 'savage natives'. The positive concept of Nativism refers to the notion of being attached to a particular place, where aliens, imported values, languages, and cultures coming from outside are resisted vehemently for the protection and survival of local culture.

Ashcroft, Griffths and Tiffin (2007: 143) define Nativism as a term for the desire to return to indigenous practices and cultural forms as they existed in pre-colonial society. The focus of Nativism is to "re-invent and reconstitute the traditions that the 'Master' had tried to destroy" (Adeyẹmi, 2003: 14). Nativism is an astute celebration of cultural nationalism, a "look back" by the Yorùbá and other African people to their "traditional civilization" as a way of subverting the center's cultural, textual and epistemological dominance. Williams and Laura (1994) define Nativism as: "the desire to return, after the catastrophe of colonialism to an unsullied indigenous, cultural tradition as in various forms of cultural nationalism" (14).

The message of these scholars is a call for going back to the root, to identify the original and relevant culture and use it to champion a definite identity for the African society. Thus, writers or critics who constitute their works in defense of their community, who speak in the name of their root, belong to this formation. Some of the arguments against the theory of Nativism are based on its call for cultural purity. Since culture is dynamic, no culture is static and Yorùbá culture cannot be an exception. Ade-Ajayi (1980) posits that African cultures were "a phenomenon of continuities, changes and adaption" (57). If this is so, how then do we locate the original culture of the Yorùbá people? The dynamism of culture makes it difficult, if not impossible to locate a pure cultural identity in any human society. So, Nativism is therefore not against 
modernity but it is against the polarization of the world culture into opposing binary: master/servant; center/ periphery; core/margin; civilized/uncivilized; self/us, European civilization/African savagery; rational/unconscious; light/darkness. Nativism rejects the ontological binarism where our traditional beliefs, values, and institutions are regarded as irrelevant. Our theoretical framework is therefore in line with the wisdom of the elders which says: ọsọ́ ọlọsọộ kò ye ni, bí ká ní tẹni; àgbàbọ șòkòtò kò yẹmọ ènìyàn, bí kó fún wọn lẹsẹe, a sọ wọ́n, rẹgírẹgi lohun ẹni í bá níi mu. (an imitated fashion does not compare with one's original creation; a borrowed trouser/pant does not completely fit the wearer. If it is not too tight, then it is too loose, one's garment is never short by an inch). Nativism by its nature is multidisciplinary in approach. Nativist theorists combine historical, political, cultural, and linguistic discourses in their analysis of literature, socio-political and historical information useful for the analysis of the selected poems are included.

\section{Obasá and the Colonial Politics in Yorùbá Society}

The recent study of Akinyemi (2017) has given us a comprehensive biography of Obasá and how he mediated between the traditional epoch and modernity. According to him, Obasa lived between 1879 and 1945 and not between 1879 and 1948 as stated by Olabimtan (1974a). His greatness as a poet, according to Akinyemi, was not only based on language and style of his poems as viewed by Olabimtan (1974b) but on the critical philosophical themes of his poems. Ọbasa was born a prince of the Giẹsi ruling house of Ile-Ife in 1879 to Prince Awole Ọbasá, and his mother was Fọlawiyọ who were working in Lagos at the time of his birth. He attended primary school in Lagos between 1886 and 1890, Baptist Academy for his secondary education between 1891 and 1896 . He could not travel overseas due to financial challenges but learned furniture making and printing. Obasá worked as a sales manager with Paterson Zichonis (PZ) in Lagos, transferred to Ibadan and later resigned in 1919 to start his own printing press. His interest in Yorùbá oral poetry started when he was 18 years old. For 31 years between 1896 and 1927, he went about learning from Yorùbá poets in order to produce his own works. He was an educated poet and also an oral poet. Akinyemi (2017) confirms that Ọbasa was a local intellectual and poet whose greatness was enhanced and consolidated by several special factors namely: his membership of the socio-cultural group Ẹbẹ Àgbà ò Tán (Elders still Exist Society), formed in Ibadan in 1909; the establishment of Ilare Printing Press; and the Publication of the weekly Yorùbá newspaper Yorùbá News. He affirms his intellectual standing in his first poem compiled in Iwe Kiíní ti Awon Akéwì. 
Extract 1

Èmi l' Akòwé Akéwi

Emi l'Akéwí Akòwé

Bí mo ti n ké kíké

Bẹe ni mo n kọ kíkọ

Ėmi a si máa tè lótitẹ (Ọbasá 1927: 2).

I am the poet's scribe

I am the literate poet;

On the one hand I recite poems,

On the other hand, I commit then into writing

Furthermore, I am a printer.

He states further that his type of poem is different from other oral poets who were mainly farmers and illiterate.

Extract II

İkéwi mi kò jọ tarà oko,

İkéwi mi kò jọ tàgbè

Ėkà tí mo bá kà tí kò bá pé

K’ẹgbẹ ó bọ mi lásọ.

E si gbà mí ni filà

Àfàṣọ àti filà,

Bọyá wọn a pégbàá mẹrin

E ò ri’n pín fún mọrìwò (Ọbasá, 1927: 2).

My poetry is not like poets in the farm

My poetry is not similar to the poems of farmers

If my counting is not complete,

Let the orchestra group remove my garment

Remove my cap

Both garment and cap

May cost two shillings

To be shared among the group members.

Extract II above shows that Ọbasá was not only a collector of traditional sayings, not only a scribe to Yorùbá oral poets but also a writer of poems in his own right. Obasá belongs to the new intelligentsia who mediates between the colonial masters and the people through his writings in the newspaper, 
using his printing press to interrogate colonial politics. In the remaining sections, I examine the socio-political commitment of Obbasa as reflected in his poems.

\section{Colonialism as Agent of Peace}

Obasa makes a lot of comment on the term 'colonialism' which he refers to as ìgbà òibó or ìgbà èèbó. Colonialism has been described in diverse ways by scholars. For example, Aziz (1980) cited in Obafemi (1997) has this to say on colonialism:

Colonialism is a particular insidious virus and when and where it strikes, it creates a profound imbalance in the human personality. You have a history yet you do not, you have a culture of your own, yet you doubt, you have a homeland of your own, yet you do not. When one's soul has to struggle with these contradictions, over decades and generations, it is no wonder, one wants to be someone else (10).

Aziz views colonialism as a virus which creates "profound imbalance in the human personality." The point Aziz is making is that, like the virus, colonialism is an agent of death and deadness, not only to the socio-cultural, but to the economic and political life of the people. Colonialism, as a deadly virus alters the people's course of history. It causes physical dislocation, mental agony, spiritual as well as cultural impairment. In Yorùbáland, colonialism has numerous negative influences on the culture of the people, but it has brought some positive changes into the socio-economic and political life. For instance, it has introduced Western political system, a new religion, formal education, and has reduced the Yorùbá language to writing. Ọbasa acknowledges the positive side of colonialism as well as the negative side. İgbà èèbó means the colonial period, when the traditional politics and governance have been taken over by the white men.

In the first poem, Iwe Kinni ti Awọn Akewi, the poet acknowledges the usefulness of formal education. He is akéwi akọwé (A literate poet), it is clear that the poet benefits from western education which is a product of colonial heritage. He is not only literate; he belongs to the elite class who is set to make poetic utterances on the colonial government's policies. He was born at a time when the dignity of the traditional rulers was being challenged by the colonial administrations across Africa. The educated elite were more recognized by the colonial masters than the traditional rulers. Prior the incursion of the Europeans into Africa, the Yorùbá kings welded enormous political power and they were highly respected; but in the $19^{\text {th }}$ century, many empires in Africa fell. Unfortunately, they lost their esteem position because of internal dissensions. Various representatives of the colonial government exploited 
the turmoil of Yorùbá politics by playing one group against another. They realized that each warring tribal king needed fire arms. They gave the kings their most desired needs. Non-government organization such as The Royals Niger Company (RNC) colluded with the colonial government to weaken the African kings who did not suspect the intention of their helps. At the end of the encounter, one king after another was made to sign a treaty. This led to a temporary peace among the warring kings. Obasá acknowledges the efforts of the colonial masters in this regard in his poem entitled "İgbà Òibó." The poet acknowledges the peace and security that followed colonial intervention:

Extract III

Ayé dayé oibó

İgbà Òibó dùn lá-dùnjù

Kò sógun mọ́

Kò sótẹ mọ́

A kò muni lóko mọ

A kò muni lódò mọ

Ta nii lọ níbẹ’un kò sí mọ́

Gbogbo wa dọmọ ọba (Obasa 1934: 52).

The white is now in-charge

The time of the white is sweeter

There is no war any more

There is no more rebellion

No one is kidnapped again on the farm

No one is kidnapped in the stream again

'Who is going there' is no more

All of us have become the offspring of the king.

Here the poet makes allusion to the pre-colonial era when wars, slavery, kidnapping and unrest covered Yorubaland, but with the coming of the Europeans, peace and security have become the first benefit of colonialism in Yorùbáland. Yorùbá political history has records of numerous inter-tribal and intra-tribal wars, the Ijaye War (1860-1862), Ekitiparapo War (1875-1893), Adubi War (1918), Owu War (1821), Egba War (1832-1834), and Jalumi War (1843). Even though Obasa did not witness some of the wars, stories of wars were part of oral narratives when he was young; and, indeed, he was alive during the Ekitiparapo War. The coming of the Europeans brought to an end to various intra-tribal and inter-tribal wars in Yorùbáland and, peace and security ensued. Ọbasa only makes a brief comment in "Elétò-ètò" on 
the dignity and honor of the institution of Obbaship in Yorùbáland before the colonial period in:

\section{Extract $1 \mathrm{~V}$}

Ilé-san-mí kò lu Gbẹdu

Ėniyàn lásán kò nílàrí,

Oba ní la'rí eni

Igba nlá kò lè pa mẹta

Eniyan mẹta kò dúró ni méji méji

Baálé ilé di méji

Itan adie di pínpín (Obasa 1927: 52).

A non-initiate does not beat $g b e ̣$ du drum

A peasant does not keep royal emissaries

It is only the king who has the authority to create royal emissaries

A big gourd does not bear three of its kind.

Three persons cannot stand in twos

When occasion demands that leaders of two families meet

The thighs of a chicken will have to be shared among them

Here the poet makes allusion to the power of the king in the pre-colonial. The king, like the family head, is the leader of all citizens. He alone had royal emissaries before the contact with The Europeans, but now the colonial administrators not only share the political power with the king but they are aspiring to take-over the power from the king completely. In Iwe Kinni ti Awon Akéwì, Obasa refers to the colonial master as ọba ti fộba je - the king who installs other kings (17). The only recognized king during the colonial period was the Queen of England, and all the colonial subjects have equal rights as children of the Queen.

\section{Colonialism as Agent of Transformation}

The transformation the poet talks about is the marked change for better in the physical appearance of cities and towns in Yorùbáland brought about by the colonial masters. The poet shares his feelings on the new system of transportation, such as good road network as against footpaths, and the introduction of rail and air transportation systems. In the pre-colonial era, travelers and visitors trek through bush-paths and carry their loads on heads or on animals like donkeys; but with coming of the colonialism, newly constructed tarred roads were opened. According to the poet, the development makes life pleasurable, easy, and beautiful for the masses. The poet states; 


\author{
Extract V \\ Ayé di jọgbọdọrúkú-njọgbo \\ Gbogbo ayé ti luja'ra wọn \\ À n re mọká, a gbọ’na Èkó? \\ A nre 'Lú Ọba (king) \\ A gbọ́na Kaduna? \\ Ọkọ kò gboju omi mọ, \\ $O n$ rin ileyile? \\ Ona ileyile kò yaá mó \\ Ojú afẹfẹ ní wọn tún n bá lọ (Obasa 1934: 52). \\ Life has become easy and pleasurable \\ There is road network everywhere \\ If we are going to Mecca, we go through Lagos? \\ If we are going to the United Kingdom \\ We go through Kaduna? \\ The vehicle does not go through the sea \\ It goes through the road \\ The road transport is no longer quicker \\ They now go by air.
}

The poet praises the Europeans for the social transformation and infrastructural facilities because life is no longer tedious in the area of human transportation. He applauds the Europeans for the provision of physical facilities. However, Obasá seems to regard the temporary peace after various political treaties and the subsequent takeover of government by the colonial masters as a trap that ensnared the Yorùbá society.

There seems to be a compelling force of nativist patriotism, cultural nationalism, and ideological commitment upon the poet, he uses his poetic utterances to present a literary evaluation of colonial political life in Yorùbáland with a view to stimulating and provoking political consciousness in the readers. His poetic utterances also focus more on the negative sides of colonial governance and its effects on the Yorùbá cultural values.

\title{
Colonialism as a Disintegrative Force
}

On the negative side, Obasa regards colonialism as a disintegrative force. Nativist theorists generally believe that colonialism brought new values that cause displacement, dislocation, and disintegration to the African communal life. Ọbasa as a literary artist, voices his feelings about the evils of 
colonialism. The poet identifies some of the political, judicial, social, and economic changes such as new transportation system, court, new marriage system, and money currency as channels of social ills, neglect of the family as a result of too much travelling away from home, unfaithfulness among married couples and love of money. He condemns the disintegrative tendencies in the colonial agenda and he makes critical comments on the alien values that invade the Yorùbá land. He states:

Extract V1

Ayé tú be

Gambari n sun rárà

Igba digba Òibó

Aya kò gbọ tọke

Omọ kò gbọ tí baba

İyàwó kò gbọ tìyálé

İwòfà ko fe sịse

Ayé pada

A pòdì àdá dà

Ewé Àlupàyídá a kò paradà mọ

Alé roju ọkọloji

O $n$ rin fanda?

O l'amúni kò sí

A bíni kò sí

Bòkọ bá fé

Kò kalọ sí Bẹrẹ (Obasa, 1934:52-53).

The world is in trouble

Gambari (Hausa) is chanting rárà

This time of the white,

The wife is disobedient to the husband

Children do not obey their fathers

The younger wife is rude to the senior wife

The serf doesn't want to work again

Life has changed

We have changed the other side of cutlass

The leaves of àlùpàyídá refused to change

The concubine is not afraid of the husband

He commits adultery with pleasure

He says no one can punish him

No one can ask him

If the husband wills 
He can go to the court in sitting in Bẹre Quarter for divorce

Here the poet condemns the official colonial policy as regards divorce. Divorce was not part of Yorùbá marriage institution, the Yorùbá people says, $a$ ki í mọkọ ọmọ kí a tun mọ àlè rẹ (lit. it is a taboo to know the husband of our daughter and also approve her concubine). A situation where a married woman would go to court and divorce her husband was strange to the people until the colonial period. In Yorùbá society prior the colonial time, settlement of marital conflict is limited to the extended family and not a government matter. So, the poet in line with the nativist point of view condemns the policy of divorce instead of peaceful resolution of marital conflicts. Obasa makes a denunciation of the irregularities and contradictions inherent in the colonial political system with strange marital laws which devalue the moral dignity attached to marriage institution in Yorùbá society. He debunks the myth of orderliness in the colonial social system because it leads to dislocation and dysfunctional relationship in the Yorùbá society. The poet continues:

Extract VII

İgbà dìgbá Òibo

Àpò ẹkùn dì kálásí ọmọde

Ekùn kú, a fọwọ́ bà á

Èsúró pàdídà ó n lájá

Ara-ọrun $n$ fire fera-aye

Baba ni $n$ rawọ́ sọmo

Ọkọ nì n rawo sáya (Obasa 1934:53).

It has become the period of the white

The lion's bag has become a child's okro bag

The lion dies and we touch it

The antelope is now chasing the hunter

The dead are at the mercy of the living

The father is begging the child

The husband is begging the wife.

The poet condemns the colonial law that truncates the tradition of the Yorùbá people on moral purity, respect for elders and constituted authority. In the pre-colonial Yorùbá society, there were no written laws or bureaucratic procedures but there were unwritten norms and conventions that guided the administrative and cultural life of the people.

The poet laments on the method of conflict resolution introduced by the colonial masters as strange and opposed to the traditional method of conflict 
resolution. In the pre-colonial era, the Yorùbá philosophy of alájọbí, the familial bond of kingship, is a powerful strategy of conflict resolution in Yorùbá society. Alájọbi inheres with a spiritual essence that is connected with the family's ancestral spirits (Olarinde, 2010: 307). Members of the extended family or kinship are bound to maintain loyalty, trust, and solidarity among themselves. When there is conflict, at the domestic level - the resolution is usually at the ancestral ground of the founding fathers. The invocation of the spirit of the ancestors who founded the kinship is usually done with respect. No matter the degree of offence in the family, once a person is begged in the name of the alájobi helshe must relax. Once an elder says: a falájọbi bẹ ọ (we appeal to you in the name of our kinship tie), whatever the degree of offence in the conflict, this statement is enough to pacify the aggrieved person. The consciousness that alájobi is invoked in the process of cross-examination during conflict resolution makes the people to be cautious when they are offended and makes the parties concerned to forgive and forget. Proactive activities help to de-escalate potential conflict, and to keep conflict from manifesting. Traditions and cultures promote community life and togetherness which down play conflicts. During the colonial period, the nature and methods of conflict resolution have changed. Colonialism introduced strange systems of conflict resolution, for example, divorce was never part of Yorùbá conflict resolution in marriage before the court system came. Whatever happened between husband and his wife or wives was settled by families amicably. The view of the people was: a kì í rí a rẹ́ má jà, a jà má rẹ ni kò dára (there is no friendship without conflict but conflict without resolution is bad). Conflict resolution became monetized and both accused and the complainant have to pay regardless of whosoever was at fault. The poet condemns the monetized colonial justice as follows:

Extract VIII

İgbà dìgbà Òibó

Eni bá n'ọgi yoo sanwó

Eni ti a nọ kò nígbài san

Eni tí kò rówó san

Erò ệọ̣n ni 'ó dà

Eni tó ságbẹ kò lówó nínú

O di firi-ri gbàgà l'Agodi (Obasa 1934: 54).

This period of the white

Whosoever fights with sticks/club will pay fine

The victim will pay a fine

He that cannot pay the fine 
Will become a prisoner

He who cuts another with cutlass

Is thrown to Agodi prison by force

With the introduction of the court system the perception changed to: a ki i ti kóotù dé sọorẹe (We do not retain friendship after a court case). The poet seems to advocate the peace -making justice of the Yorùbá society rather than the retributive justice of the colonial masters. Any resolution technique or method that is not made to bring peace to disputants is inadequate and cannot stand the test of time.

\section{Wars in Yorùbáland and the Politics of the First World War}

Obbasa also makes poetic utterances on the years of wars in Yorùbáland and the politics of the First World War orchestrated by the imperial lords. Arogundádé (2017) explains that the $19^{\text {th }}$ century was one of inter-group warfare that led to monstrous political, economic, demographic and social consequences (649). Such wars were Owu (1813-1814; and 1821-1826), Ijaye (18601862), and Ekitiparapo also known as Kíriji War. The people were displaced and forced to live as refugees in other kingdoms. The issues involved in the series of wars were diverse in Obasa's views as portrayed in the poem entitled: "Adámálèșe." The poet states:

Extract IX

Ogun torí kánun

Ogun ja'le Awusa tán

Ogun kò mú kánun lọ

Ogun torí oja

Ogun ja 'Jaiye

Ogun kò mọ́jà lọ!

Ogun torí àgbọn jà 'Kèrèkú

Ogun jà Kèrèkú tán, Ogun kò máàgbọn lọ!

A ni "E má k'Égbè

Nwọn ní kíkó ni!

Ogun burú ilú kò dùn

Ọkọ̣kan lá bọ ogun Eggbẹ (Obasa 1934:21).

Because of potash

War invades Hausaland

The war did not carry away the potash 
Because of market

War invades Ijaiye

The war did not carry away the market

Because of coconut

War destroys Kèrèkú completely

The war did not carry away the coconut

We instructed that Ẹgẹ̀ should not be invaded

They insisted on its invasion

War is evil, there is peace in the town

We escape from Egbè war one by one

The poet identifies economic determinism as critical issue in Yorùbá intra-tribal and inter-tribal wars. Some economic products such as potash, market, coconut mentioned by the poet as reasons for the wars are used as metaphor. Metaphor is everywhere in Obasa's poems. Metaphor generally has a decorative purpose because it makes poetry exciting and beautiful, however, in Obasa's poetry, it serves to highlight important themes, it helps readers to deepen their understanding. Potash (Kánún), stands for mineral resources, market (ojà) symbolizes the pillar of economic activities while coconut (àgbon) has to do with boundary or land issue.

The poet also reflects on the First World War and blames Napoleon the German leader as aláșejù which is the title of the poem. Alásejù means an over-doer, he who acts in excess. In lines 49-53, the poet says:

\section{Extract X}

Oba Jamani

Òun laláṣejù, Òun lọyájú!

Tó ní òun 'ó șebi (Obasa, 1927:23).

The German king

He is the over-doer, he is the trouble-maker!

He vows to do evil.

The poet uses wordplay to describe the evil intention of the German king:

Extract XI

Oba Nàpó, Nàgiri Napoleon

Ọba nà kòkò, nà saasùn

Oba n'awo n"egbẹri

Oba n’olóógun-n’olóógun (Obasa 1927: 23). 
The king that beats 'pillar and wall'

The king that beats 'big and small pots'

The king that beats 'cult members and non-initiates'

The king that beats military men

The noun phrase 'Nàpò' is Yorubanized and it means 'beat the pillar', and the poet uses it as a wordplay- Nàpó, nàgiri, nàkòkò, nà saasùn, nawo nẹgbẹrì to show him as a ruthless, vicious and dangerous war monger who caused the war that affected the colonial subjects. He acknowledges the efforts of the British warlord (Lord Kitchener) which he calls "Kíṣínà Olórí Ogun Ọba Gẹẹsì" and Wilhemina the Queen of England. He rebukes William II the German king who fled when Napoleon was captured as St. Helina. The poet states:

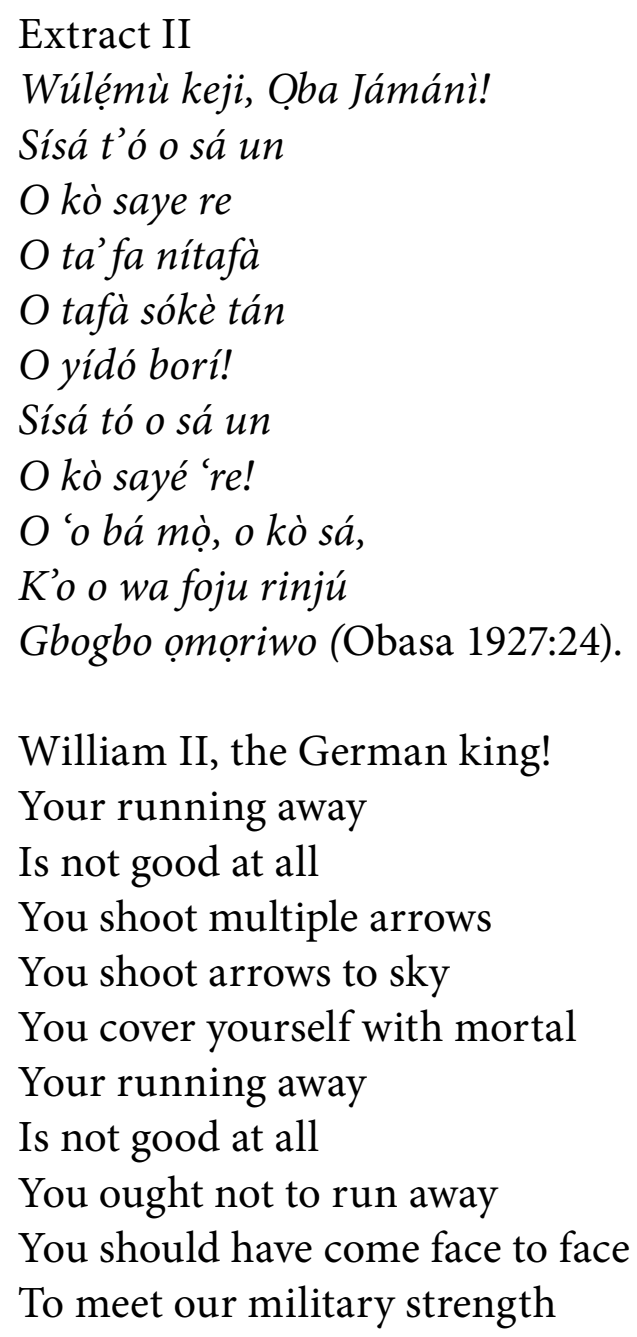

The poet accuses the German leader of underestimating the strengths of the allied forces and compares the actions of Napoleon with a house rat who 
challenges the cat to a battle or a dog that asks a leopard to a combat, disgrace will be his end. He says:

Extract XII

Àimọkan àimọkàn

Nií mú èkúté ilé

Pológbò n'ijà

Aláșejù lajákájá

Tín lépa ẹkùn (Obasa 1927:25).

It is pure ignorance

That makes a house rat

To invite the cat to a battle

Any dog that acts in excess

Will pursue a leopard

The poet asserts that colonialism alone bears full responsibility for the two World wars, the most destructive and costly wars in history. Many lives were lost and millions of hard currencies were wasted on the wars. He blames the German leaders for using politics beyond the acquisition of political power but also for economic and selfish reasons. Thus, Obasa accuses the German leaders for fueling the war of expansion, war of economic exploitation and war of power which negatively affects Yorùbá land during the colonial era.

\section{Political Commitment and Ideological Standpoint of Obasa}

The notion of political commitment in Nativist theory is that committed literature must be able to persuade the people in a society to reflect and meditate upon their lives. Such commitment must be located within the indigenous knowledge system of the society to stimulate critical thinking which will lead to progressive action for the good of the society.

Obbasá is committed to the Yorùbá ideals and his poetic utterances imaginatively reject and negate whatever is anathema and inimical to the socio-political welfare of the Yorùbá people during the colonial period. Colonial literature in Africa, according to Wauthier (1978: 24) is divided into four types. These are the politically committed, the pro-colonial literature, the conformist, and the neutral. The politically committed literature negates colonialism forthright. The pro-colonial literature admires, supports and encourages colonial ideology without question. Conformist literature is not involved in the colonial controversy, but reflects the teaching of missionaries and colonial officers in their works. The works of those writers who reject the temptation 
of political claims are considered neutral. Olabimtan (1974a) identifies three kinds of Yorùbá poets during the colonial period namely: 'compromise poets', 'colonial poets' and 'protest poets'. He categorizes Obasa and OQdunjo as poets who employ poetry as a means of showing their indignation to disapprove of wrong-doings.

From the analysis of Obasa's poetic utterances, his political commitment and ideological standpoint can be located within the progressive camp. Progressive ideology is from the word "progress." Progressives generally tend to see themselves as people who believe in reform, in changing the society for the better, as opposed to conservatives, who want to keep things the same or even turn the clock back. Progressives are socially liberal. The titles of some of the selected poems do not suggest radical ideology or neutral ideology. For example, titles under which socio-political themes are embedded do not portray abusive or derogatory colorations- "Elétò-ètò" "Aláșejù" in İwé Kinni Awọn Akéwi, and "Adámáleșè", "Ilu Ilọrin", and "İgbà Òibó" in İwé Kejì Awọn Akéwi. The contents of the poems are not meant to reject colonial modernity. They are mostly to inform, educate, and sensitize the readers on the structural political changes in Yorùbá land. Obbasa does not call for the total rejection of colonial modernity, rather he advocates a careful selection of the new socio-political values brought about by the colonial powers. He protests against some of the social ills which colonial politics has brought to Yorùbá land particularly lack of respect for indigenous political system, removal of Yorùbá kings from the new political structure, love of money, court system which brings enmity in the society, unfaithfulness in marriage leading to divorce, migration to cities and dislocation of communal family system. His call for reform or change therefore is not a call for violence but a call for systematic, cautious and peaceful rejection of colonial policies which are detrimental to Yorùbá values. In the poem entitled: "Pẹ̀lẹpẹ̣lẹ," he says:

Extract XIV

Pẹlệpẹlé, pẹlệpẹlé

Pẹ̀lé larẹwà $n$ rìn

Jẹéjẹ lọmo ọlọlá n yan

Igbá onípẹlé kì í fọ́

Àwo onípẹlé ki i fàya

Ohun a fẹlè mú kì í bàjé

Ohun a fagbára mú

Koko-ko nií le! (Ọbasa 1927: 13).

Be cautious be cautious

The pretty one walks with caution 
Offspring of dignitaries walk with caution

The calabash of cautious person does not easily break

The plate of a cautious person does not easily break

What we handle with caution is never spoilt

What we take by force

Is always hard

\section{Conclusion}

Opbasa, as a committed poet in the progressive camp, is neither violently against the colonial ideology nor actually in support of it. He embraces the positive sides of colonial policies such as western education, good road and rail transportation systems, but also protests against the social ills brought about by the colonial modernity. Thus, the ideological standpoint of Ọbasa is to transform the consciousness of the citizens by using his poems for political education through which peoples' minds are awakened to the political changes during the colonial period. As a progressive political poet, he calls for caution in our embrace of colonial political legacies. Obasa's advice on the need to be cautious in accepting or attacking colonial legacies is still relevant to modern Nigeria particularly in Yorùbá land. He warns the Yorùbá people of his generation not to completely accept colonial political order but tread softly with foreign socio-political values. The most critical issue in Yorùbá political space today is 'restructuring'. It must be pursued with tact, caution and peace. This is a useful and potent advice to every society which has been caught in the web of colonialism and neo-colonialism. The poet warns:

Extract XV

A kò lè pé İgbà Òibó

Ká fojú egbọ tẹlè

Eni bá fojú egbò tẹlè

Dídá ní n dá kún un (Obasa 1934: 53).

We cannot say we are in the period of the white men

And walk with a sore leg barefooted

Whosoever walks with sore leg barefooted,

Will complicate the pain.

\section{References}

Ade-Ajayi, J.F. Resilience of African tradition, African's Unity: The cultural foundations. Lagos: CBAAC, 1980. 
Adeyẹmi, O. "The Yorùbá Novel and Political Consciousness: A study of the works of Owólabí, Yemitan, Olabimtan and Abiọdun.” Unpublished Ph.D. thesis, University of Ilorin, Ilorin, 2003.

Akinyẹmí, A. D.A. Ọbasa (1879-1945): "A Yorùbá Poet, Culture Activist and Local Intellectual in Colonial Nigeria." Africa. 87.1, (2017): 1-15.

Arogundade, N.O. "War and Diplomacy." In Toyin Falọla and Akintunde Akinyẹmi, (eds.) Culture and Customs of the Yorùbá, pp. 295-308. Austin, Texas: Pan-African University press, 2017.

Aschroft, B. Griffiths, G. \& Tiffin. H. Post-colonial Studies: The Key Concepts. London and New York: Routledge, 2007.

Babalọla, A. and A. Gerard. "A Brief Survey of Creative Writing in Yorùbá" Review of National Literature 2.2, (1971): 191.

Chinweizu, O. \& Ihechukwu, M. Towards the Decolonization of African Literature. Washington DC: Howard UP, 1090.

D'Almeida, Y. "Political and Social Commitment and the Problem of Audience in African Literature." Seminar Paper. Department of English, University of Ibadan, 1974.

Dasenbrock, R. Initial. "Poetry and Politics." In N. Roberts (ed.) A Companion to Twentieth Century Poetry, pp.51-63. Oxford: Blackwell, 2001.

Folorunșo, A. O. (1998). The written Yorùbá poetry 1949-1989: A study in the sociology of literature, Unpublished Ph.D. thesis. Ibadan: University of Ibadan.

Kirpal, S. "Political Commitment and Poetic Utterance: Post-Independence Poetry from Singapore and Malaysia. Hena." Kristen and Ruthford (eds.) A Shaping of Connections, Commonwealth Literature Studies, Then and Now, pp. 181-191 Australia; Dangaroo Press, 1989.

Kumar, P. (2014). “Socio-political Commitment in Seamus Heaney's Poetry. Asian Research Consortium - Asian Journal of Research in Social Science and Humanities. 4.11, (2014): 178-183.

Nemade, B. Nativism in Literature. Trans. Makarand Paranjape, in Makarand Paranjape (ed.) Nativism essays in criticism. New Delhi: Sahitya Akedemi, 1996.

Ọbafẹmí, O. Literature and Society on the Border of Discourse. Inaugural Lecture, University of Ilorin, Nigeria, 1997.

Obasa, D. A. İwé Kinni ti Awon Akéwì. Ibadan: The Ilarẹ Press, 1927.

Obasa, D. A. İwé Kejì ti Awon Akéwì. Ibadan: Government Printers, 1934.

Obasa, D. A. İwé kẹta ti Awon Akéwì. Ibadan: The Ilarẹ Press, 1945.

Ogunsina, B. The Sociology of Yoruba Novel: Introduction. Ilorin: University of Ilorin, 2006.

Olabimtan, A. "A critical study of Yorùbá written poetry (1848-1948)." Unpublished Ph.D. Thesis Lagos: University of Lagos, 1974a. 
Ọlabimtan, A. "Language and Style in Ọbasa's Poetry." In W. Abimbola (ed). Yorùbá Oral Tradition: Poetry in Music, Dance and Drama. Pp.1031-1069, Pp 00-00, Ile-Ifẹ: Department of African Languages and Literatures, University of Ifẹ, 1974b.

Olarinde, N. "Traditional Beliefs and Practices in the Sustenance of "Peace." In Olawale, A. and I.O Oloyede (eds.) Dynamics of Peace Processes. Ilorin: Centre for peace processes. Pp.306-307) 00-00, Ilorin: Centre for Peace and Strategic Studies, Ilorin, University of Ilorin, 2010.

Rylance, R. (Ed). Debating Tests: A Reader in Twentieth Century Literary Theory and Method. Milton-on-Keynes: Open University Press, 1987.

Wauthier, C. The Literature and Thoughts of Modern Africa. (Second English Language Edition) London: Heinemann, 1978.

Williams, P. and Laura, C. Colonial Discourse and Post-colonial Theory: A Reader. New York: Columbia University press, 1994. 